\title{
SUPERCRITICAL FLUID EXTRACTION OF CORN GERM OIL: STUDY OF THE INFLUENCE OF PROCESS PARAMETERS ON THE EXTRACTION YIELD AND OIL QUALITY
}

Sara Rebolleda, Nuria Rubio, Sagrario Beltrán, M. Teresa Sanz *, and María Luisa González

Department of Biotechnology and Food Science. University of Burgos. Plaza Misael Bañuelos s/n. 09001 Burgos. Spain. Tel.: +34 947 258810. Fax: + 34947 258831. Email: tersanz@ubu.es

\begin{abstract}
The supercritical fluid extraction of corn germ oil has been studied in this work. Extractions were carried out at different pressure, temperature and flow rate to analyse the influence of these variables on the extraction kinetics and the oil quality obtained. Extraction curves are initially linear with a slope close to the oil solubility value in supercritical $\mathrm{CO}_{2}$. Based on these results a mathematical model was successfully applied to describe the extraction curves. Characterization of supercritical crude corn oil was performed by determining some physical parameters such as refraction index, density and color. Additionally, the fatty acid composition, neutral lipids, the content of tocopherols, acid index, peroxide value, antioxidant capacity and the oxidative stability
\end{abstract}

${ }^{*}$ Corresponding author 
were determined in the corn oil extracted. Fatty acid composition was compared with that for crude germ oil and no significant differences between the oils extracted by both methods were found. Oxidative stability test using the Rancimat showed that supercritical $\mathrm{CO}_{2}$ extracted corn oil is less protected against oxidation than $n$-hexane extracted oils.

\section{Keywords}

Supercritical fluid extraction. Corn germ oil. Tocopherol. Sovová’s model

\section{Introduction}

Traditionally, the extraction of corn germ oil has been done by physical and chemical methods. In these conventional methods, the oil is removed from the milled germ using a conditioning (heating) process, followed by mechanical expelling (prepress) and in some cases ending up with hexane extraction. Extrusion has been also employed to prepare the germ for solvent extraction leading a crude corn oil of high quality and high yield [1]. After oil extraction, the bagasse obtained as raffinate is normally used for animal nutrition.

The supercritical fluid extraction (SFE) of corn gem oil has been studied by several authors. List et al. [2, 3] and Christianson et al. [4] compared the quality of crude oils obtained from dry and wet milled corn germ by SFE at $50-90{ }^{\circ} \mathrm{C}$ and $55-83 \mathrm{MPa}$ and by conventional extraction methods. The oil obtained by supercritical $\mathrm{CO}_{2}$ extraction exhibited lower refining loss and lighter color. List et al. [2] found that, in general, crude oil quality was unaffected by extraction conditions. The levels of tocopherols present in $\mathrm{SC}-\mathrm{CO}_{2}$ extracted corn oil are similar to those obtained by conventional 
methods [2, 3]. However the phospholipids are almost absent in the $\mathrm{SC}-\mathrm{CO}_{2}$ oils which is an advantage from a processing point of view.

Wilp and Eggers [5] proposed an extraction process followed by a fractionation separation step to improve the oil quality since low polar triglycerides could be separated from high polar compounds such as water and free fatty acids.

Vigh et al. [6] reported extraction curves of wet corn germ oil with $\mathrm{SC}-\mathrm{CO}_{2}$ in an interval of pressure (27.0-33.0 MP) and temperature $\left(42-78{ }^{\circ} \mathrm{C}\right)$ and at particle size $<0.8 \mathrm{~mm}$ or $0.8-1.4 \mathrm{~mm}$. Based on a second order orthogonal design, Vigh et al. [6] concluded that for the smaller particle size range, application of low pressures and high temperatures should be avoided. Rónyai et al. [7] studied the $\mathrm{SC}-\mathrm{CO}_{2}$ extraction of wetmilled corn germ oil with cosolvents (ethyl alcohol: from $0 \%$ to $10 \%$ by weight in $\mathrm{CO}_{2}$ ) at a constant pressure and temperature (30 $\mathrm{MPa}$ and $42{ }^{\circ} \mathrm{C}$ ). The extraction time was reduced due to the higher solubility of corn oil with increasing ethanol concentration although the amount of phospholipids in the oil was higher.

In addition to oil, SFE of corn germ also results in an interesting defatted corn germ flour, due to its low fat content and lower peroxidase activity when compared to hexane extracted corn germ flour, which lead to a larger storage stability and better flavor [4, 8, 9]. Rónyai et al. [7] found that the emulsifying, foaming and absorption properties of the defatted meals and its protein isolates were better when using ethyl alcohol as cosolvent.

The aim of this work is the study of the influence of some extraction parameters such as pressure, temperature and solvent flow rate on the corn germ oil extraction rate. New extraction curves have been obtained than those reported in the literature. In addition, the quality and stability of corn germ oil obtained by SFE, with and without 
fractionation, was evaluated under different extraction conditions. Quality and stability parameters not evaluated before in corn germ oil extracted with $\mathrm{SC}-\mathrm{CO}_{2}$, such as antioxidant capacity, have been determined.

\section{Experimental section}

\subsection{Raw material}

The raw material used in this work was corn germ with an average moisture content of $6.0 \pm 0.4 \%$ and $46 \pm 3 \%$ average fat content as determined by Soxhlet extraction with petroleum ether. Regarding the moisture content, Christianson et al. [4] reported that, at this level, it plays a minor role in SC- $\mathrm{CO}_{2}$ extraction of corn germ oil not affecting the extraction efficiency or the ultimate oil yield. The corn germ was milled in a coffee grinder to a particle size ranging from $0.5 \mathrm{~mm}$ to $1 \mathrm{~mm}$.

\subsection{Supercritical fluid extraction equipment and procedure}

The extraction experiments were carried out in a semi-pilot SFE-plant whose P\&I diagram has been presented elsewhere [10]. The usual elements of an SFE-plant with solvent recycling were installed, i.e.: pump, extractor, separator, heating and cooling systems and pressure dampers; rupture disks and safety valves were installed for safety and instruments for measurement and control of the process parameters. The maximum specifications of the SFE-plant are: $T=200{ }^{\circ} \mathrm{C}, p=65.0 \mathrm{MPa}$ and solvent flow, $Q=$ $20 \mathrm{~kg} / \mathrm{h}$.

In a SFE experience, $350 \mathrm{~g}$ of corn germ were placed in the extractor mixed with an inert filling in order to avoid bed compactation. The extractor was later pressurized with $\mathrm{CO}_{2}$ (Carburos metálicos, liquid $\mathrm{CO}_{2} \geq 99.9 \%$ ) up to the extraction pressure. Then, the solvent was circulated at the desired extraction temperature, $T$, with a certain solvent 
flow, $F$, and during a specific time, $t$. The solvent was continuously recycled to the extractor after removing the solute in the separator.

A total of fifteen experiments under the different extraction conditions reported in Table 1 were carried out. Runs 1 to 8 were performed to study the influence of temperature, pressure and solvent flow rate on the extraction kinetics. Runs 9 to 12 were performed to evaluate the influence of the extraction temperature on oil quality, runs 9 and 10 were carried out at $56{ }^{\circ} \mathrm{C}$, and runs 11 and 12 were carried out at $84{ }^{\circ} \mathrm{C}$. Additionally, three experiments (R13-R15) with a subsequent fractionation in two separators installed in series were carried out. The first separator was maintained at $10.0 \mathrm{MPa}$ and $40{ }^{\circ} \mathrm{C}$ in order to recover the less soluble compounds (triacylglycerides), and the second one at 4.0 $\mathrm{MPa}$ and a temperature of $40{ }^{\circ} \mathrm{C}$. Most of the water was found to be recovered in the second separator.

\subsection{Analytical methods}

Physical oil properties

Some important parameters like refraction index (Milton Roy abbe-type refractometer), density (densimeter model DMA 5000, Anton Paar) and color (CIELab parameters) were evaluated in the different oils extracted. CIELab parameters were calculated automatically by a suitable programme installed in a Beckman DU-650 spectrophotometer with diode-array of UV-Vis (Analytical Development Center, Beckman Instruments Inc., 1995), using the illuminant D65 (daylight source) and a 10 standard observer (perception of a human observer) following the CIE recommendations [11]. 


\section{Determination and quantification of fatty acids profile}

The fatty acids profile was determined by the AOAC method [12]. The fatty acid methyl esters were firstly prepared and then analyzed by gas chromatography (GC) in a Hewlett Packard gas chromatograph (6890N Network GC System) equipped with an auto-sampler (7683B series) and a flame ionization detector (FID). The separation was carried out with helium $(1.8 \mathrm{~mL} / \mathrm{min})$ as carrier gas. A fused silica capillary column (OmegawaxTM-320, 30m $\times 0.32 \mathrm{~mm}$ i.d.) was used. The column temperature was programmed starting at a constant temperature of $180{ }^{\circ} \mathrm{C}$ for $20 \mathrm{~min}$, heated to $200{ }^{\circ} \mathrm{C}$ at $1{ }^{\circ} \mathrm{C} / \mathrm{min}$, held at $200{ }^{\circ} \mathrm{C}$ for $1 \mathrm{~min}$, heated again to $220^{\circ} \mathrm{C}$ at $5{ }^{\circ} \mathrm{C} / \mathrm{min}$ and finally held at $220^{\circ} \mathrm{C}$ for $20 \mathrm{~min}$. A split injector $(50: 1)$ at $250^{\circ} \mathrm{C}$ was used. The FID was also heated to $250{ }^{\circ} \mathrm{C}$. Most of the fatty acid methyl esters were identified by comparison of their retention times with those of chromatographic standards (Sigma Chemical Co.). Their quantification was made by relating the peaks area to the area of an internal standard (methyl tricosanoate) as indicated by the AOAC method [12]. Calibration curves were made for several pairs formed by the internal standard + several representative chromatographic standards in order to find the corresponding response factors.

\section{Determination of neutral lipids}

The total amount of neutral lipids was determined by liquid chromatography [13] in a HPLC system (Agilent 1200) formed by a quaternary pump and an auto-injector. Separations were carried out at room temperature in a column (Lichrospher Diol $5 \mathrm{~mm}$, $4 \times 250 \mathrm{~mm}$ ) and detection was performed in an evaporative light scattering detector (Agilent 1200 series) at $35^{\circ} \mathrm{C}$ and $0.35 \mathrm{MPa}$. The mobile phase consisted of (A) 
isooctane and (B) methyl tert-butyl ether:acetic acid (99.9:0.1). The solvent gradient used was as follow: first, solvent A was flowing for 1 min, after that, solvent B was added in three steps, up to $10 \%$ in $10 \mathrm{~min}$, to $44 \%$ in $22 \mathrm{~min}$ and to $100 \%$ in $30 \mathrm{~min}$. Finally, the stationary phase was rinsed with solvent A for 5 min. Total solvent flow rate was kept constant at $1 \mathrm{~mL} / \mathrm{min}$ all along the analysis. Calibration was carried out using standards of palmityl palmitate (99\%), tripalmitin (>99\%), dipalmitin (99\%), monopalmitin (99 \%), palmitic acid (99 \%) and $\beta$-sitosterol in isoctane.

\section{Determination and quantification of tocopherol profile}

Tocopherols determination in corn germ oil was done using HPLC-DAD after isolation by solid phase extraction (SPE).

Solid phase extraction. The silica cartridge (1000 mg/ 6 mL, Sep-Pak ${ }^{\circledR}$, Waters, Spain) was conditioned with $5 \mathrm{~mL}$ of $n$-hexane before the application of $1 \mathrm{~mL}$ of $n$-hexane oil solution $(0.1 \mathrm{~g} / \mathrm{mL})$. The elution of the analytes was done with $5 \mathrm{~mL}$ of $n$-hexane, followed by $5 \mathrm{~mL}$ of $n$-hexane-diethylether $(99: 1, \mathrm{v} / \mathrm{v})$ and $50 \mathrm{~mL}$ of $n$-hexanediethylether (99:2, v/v). The collected fractions were evaporated under reduced pressure at $45{ }^{\circ} \mathrm{C}$. The dry residue obtained was dissolved in $1.5 \mathrm{~mL}$ of $\mathrm{n}$-hexane for HPLC analysis.

High Performance Liquid Chromatography. Tocopherols were performed according to a modification of the IUPAC method [14] using an Agilent HPLC (series 1100) equipped with ChemStation software, a degasser (G1322A), a quaternary pump (G1311A), an autosampler (G1329A), a column oven (G1316A) and a diodo array detector (G1315A). The column used was ACE 5 silica 250 x 4,6 mm. The mobile phase was 99\% hexane (A): 1-\% 2-propanol (B). An isocratic gradient was used and the total run 
time was $15 \mathrm{~min}$. The injection volume was $50 \mu \mathrm{l}$. All tocopherols were monitored at $296 \mathrm{~nm}$ at a flow rate of $1 \mathrm{~mL} / \mathrm{min}$.

Individual compounds of $\alpha$-, $\beta$-, $\gamma$ - and $\delta$-tocopherols were identified and quantified using a calibration curve of the corresponding standard compound.

Acid index (AI) and peroxide value (PV)

The acid index and the peroxide value of the oils have been determinated according to Ca 5a-40 and Cd 8-53 AOCS Methods respectively. An automatic titrator Methrom 905 Titrando was used.

Determination of antioxidant capacity: DPPH assay

Free radical scavenging capacity of corn germ oil was evaluated using 2,2-diphenyl-1picrylhydrazyl radical (DPPH') [15]. Briefly, $4 \mathrm{~mL}$ of $\mathrm{DPPH}^{\bullet}$ solution $(0.1 \mathrm{mM})$ was mixed with $1 \mathrm{~mL}$ of an isooctane corn germ oil solution $(0.02 \mathrm{~g} / \mathrm{mL})$. The absorbance at $517 \mathrm{~nm}$ was measured (Hitachi U-2000 spectrophotometer) against a blank of pure isooctane after the reaction was carried out at ambient temperature and darkness for 30 min. Results were expressed in mmol of BHT/g oil, using the relevant calibration curve described.

\section{Oxidative stability}

The oxidative stability was evaluated using the rancimat test that was performed with a Metrohm 743 Rancimat using a $1.5 \mathrm{~g}$ oil sample, a temperature of $110^{\circ} \mathrm{C}$ and an air flow rate of $9 \mathrm{~L} / \mathrm{h}$. 


\section{Results and discussion}

\subsection{Influence of process parameters on the extraction yield}

Supercritical fluid extraction (SFE) of a solute from a solid raw material may involve three different stages: internal mass transfer, phase equilibrium and external mass transfer. Thus, oil extraction yield may be highly affected by operational parameters such as solid pretreatment, extraction pressure and temperature and solvent flow rate. The effect of extraction temperature on the extraction yield was evaluated from $40^{\circ} \mathrm{C}$ to $85{ }^{\circ} \mathrm{C}$ at a constant pressure of $45.0 \mathrm{MPa}$ (runs 1-4) and a $\mathrm{SC}-\mathrm{CO}_{2}$ flow rate around $9 \mathrm{~kg} / \mathrm{h}$. The results are shown in Figure 1 where it can be observed that the higher the temperature the higher the extraction rate, which may indicate that, at this pressure, the increase of oil vapor-pressure with temperature is more important than the decrease in SC- $\mathrm{CO}_{2}$ density. As it is well established in literature [16], an increase of seed oil solubility with extraction temperature can be significant when the process is performed at pressures higher than $40 \mathrm{MPa}$, pressure at which a crossover behavior is usually observed in vegetables oils [16].

Regarding the effect of pressure, several extraction curves were obtained for pressures from $21 \mathrm{MPa}$ to $53 \mathrm{MPa}$ at two different temperatures around $40{ }^{\circ} \mathrm{C}$ and $80{ }^{\circ} \mathrm{C}$ (runs 1,6 and 3, 5 and 7) and a $\mathrm{SC}-\mathrm{CO}_{2}$ flow rate around $9 \mathrm{~kg} / \mathrm{h}$. The results are shown in Figures $2 \mathrm{a}$ and $2 \mathrm{~b}$ respectively. In both cases, the extraction curves indicate that, at a constant temperature, the higher the pressure the higher the extraction rate, what may be attributed to the higher density of $\mathrm{SC}-\mathrm{CO}_{2}$ which leads to higher solvent power. An increase of oil solubility when extraction pressure is increased has been reported for dry-milled corn germ [4] and other seed oils [8]. As it will be explained in section 3.2, 
the first part of the extraction is controlled by this thermodynamic parameter and it can be fitted to a straight line. Figure $2 \mathrm{~b}$ indicates that the extraction at the lowest pressure (run 6, $21 \mathrm{MPa}$ ) is very slow which may be due to the low solubility of seed oil in SC$\mathrm{CO}_{2}$.

The effect of solvent flow rate has been studied at a constant pressure and temperature of $45 \mathrm{MPa}$ and $79^{\circ} \mathrm{C}$ respectively. Two different solvent flow rates were applied, 4 and $9 \mathrm{~kg} \mathrm{CO} / \mathrm{h}$ (run 8 and 3). From Figure 3 it can be concluded that extraction curves expressed in dependence on the solvent-to-feed ratio are not significantly affected by SC- $\mathrm{CO}_{2}$ flow rate. This behavior supports the fact that solubility, but not external mass transfer, controls the extraction process.

\subsection{Modelling of the supercritical fluid extraction}

In this work, the model proposed by Sovová [17] was used to describe the experimental extraction curves. This type of model assumes that the solute is regarded as a single pseudo compound. This simplification can lead to some errors since several components are generally involved in the extraction of a seed oil [18]. In the model of Sovová the extraction yield is expressed as:

$\mathrm{e}=\frac{\mathrm{E}}{\mathrm{N}_{\mathrm{m}}}$

where $\mathrm{E}$ is the amount of extract $(\mathrm{kg})$ and $\mathrm{N}_{\mathrm{m}}$ the charge of insoluble solid $(\mathrm{kg})$ in the extractor. The dimensionless amount of solvent consumed is obtained by:

$\mathrm{q}=\frac{\mathrm{Qt}}{\mathrm{N}_{\mathrm{m}}}$

where $\mathrm{Q}$ is the solvent flow rate $(\mathrm{kg} / \mathrm{h})$ and $\mathrm{t}$ the extraction time $(\mathrm{h})$. Based on this model, the extraction curves consist of two parts. During the first one, the easily 
accessible solute from broken cells is transferred directly to the fluid phase, while in the second one the solute from intact cells diffuses first to broken cells and then to the fluid phase.

For vegetable oil extraction, Sovová [17] found that extraction curves are initially linear with a slope close to the value of oil solubility in $\mathrm{CO}_{2}$. From the extraction curves the initial slope was calculated and compared with data of solubility of oil in carbon dioxide. In a recent study del Valle et al. [19] propose a general equation to predict the solubility of vegetable oils in high-pressure $\mathrm{CO}_{2}$ (within $\pm 40 \%$ of experimental values) based on a function of solvent density $(\rho)$ and absolute temperature (T), since solubility data of various vegetable oils are similar:

$\mathrm{C}_{\text {sat }}\left(\mathrm{g} \cdot \mathrm{kg}^{-1}\right)=8.07\left(\frac{\rho}{910}\right)^{\left[9.59-8.45\left(\frac{\rho}{910}-1\right)-23.0\left(\frac{\rho}{910}-1\right)^{2}\right]} \exp \left\{-4182\left[1-259\left(\frac{1}{\mathrm{~T}}-\frac{1}{313}\right)\right]\left(\frac{1}{\mathrm{~T}}-\frac{1}{313}\right)\right\}$

Del Valle et al. [19] state that Eq. (3) can be applied to systems pure oil + high-pressure $\mathrm{CO}_{2}$ as well as to oil containing vegetable substrates, since the initial stages of the extraction process is typically solubility-controlled. To compare the initial slopes of the extraction curves, data obtained at a process temperature different from $40{ }^{\circ} \mathrm{C}$ ( $\mathrm{T}=313.15 \mathrm{~K}$ ) were divided by the temperature-correction term (TCT) of the general model proposed by del Valle et al. [19]:

$$
\text { TCT }=\exp \left\{-4182\left[1-259\left(\frac{1}{\mathrm{~T}}-\frac{1}{313}\right)\right]\left(\frac{1}{\mathrm{~T}}-\frac{1}{313}\right)\right\}
$$

The corrected (at $40{ }^{\circ} \mathrm{C}$ ) initial slope values obtained from the first part of the extraction curves have been plotted in Figure 4 as a function of pure $\mathrm{CO}_{2}$ density. In this Figure, the prediction of the oil solubility from the General Model proposed by del Valle et al. [19] together with the error limit of this model has been also plotted. As it can be 
observed, the values of the slope of the first part of the extraction are within the error limits for solubility of vegetable oil in $\mathrm{CO}_{2}$.

Rónyai et al. [7] also observed a linear increase at the beginning of the process in the study of SFE of corn germ with carbon dioxide-ethyl alcohol mixtures. They also explained that, the solvent is saturated with oil in the first stages of the extraction and solubility of the corn germ oil can be determined from this linear part. The value obtained by Rónyai et al. [7] has been also plotted in Figure 4. In this Figure, the solubility values of corn germ oil at $40{ }^{\circ} \mathrm{C}$ obtained by Soares et al. [20] have been also included.

Based on these results, equation (5) and equation (6) proposed by Sovová [17] were used to evaluate the first and second part of the extraction curve, respectively:

$\mathrm{e}=\mathrm{qy}_{\mathrm{s}}$, for $0 \leq \mathrm{q} \leq \mathrm{q}_{\mathrm{c}}$

$e=x_{u}\left[1-C_{1} \exp \left(-C_{2} q\right)\right]$, for $\mathrm{q}>\mathrm{q}_{\mathrm{c}}$

$\mathrm{C}_{1}$ and $\mathrm{C}_{2}$ are adjusting constants, $\mathrm{y}_{\mathrm{s}}$ is the experimental solubility datum, $\mathrm{q}_{\mathrm{c}}$ the crossing point and $\mathrm{x}_{\mathrm{u}}$ is the solute concentration in the untreated solid (kg solute/kg insoluble solid). The concentration in the untreated solid, $x_{u}$, was calculated from the oil content in the corn germ, being $x_{u}=0.8467$. The constants $C_{1}$ and $C_{2}$ of the model were obtained by minimizing the root squared mean deviation between experimental and calculated yield [21]:

O.F. $=\frac{\sum_{\mathrm{i}=1}^{\mathrm{n}}\left[\left(\mathrm{e}_{\exp }-\mathrm{e}_{\text {calc }}\right) / \mathrm{e}_{\text {exp }}\right]^{2}}{\mathrm{n}}$

by using the Simplex-Nelder-Mead method. The calculated extraction curves are plotted in Figures 1-3. From these Figures a good agreement can be observed between 
experimental data and model correlation. According to Sovová [17], the volumetric fraction of broken cells in the particles, called grinding efficiency, $r$, and the solid-phase mass transfer coefficient, $\mathrm{k}_{\mathrm{s}} \mathrm{a}_{\mathrm{s}}$, can be estimated from constants $\mathrm{C}_{1}, \mathrm{C}_{2}$ and co-ordinate $\mathrm{q}_{\mathrm{c}}$ at the crossing point:

$\mathrm{r}=1-\mathrm{C}_{1} \exp \left(-\mathrm{C}_{2} \mathrm{q}_{\mathrm{c}} / 2\right)$

$\mathrm{k}_{\mathrm{s}} \mathrm{a}_{\mathrm{s}}=(1-\mathrm{r})(1-\varepsilon) \dot{\mathrm{Q}}_{2} / \mathrm{N}_{\mathrm{m}}$

In equation (9) solvent flow rate is expressed in $\mathrm{kg} \cdot \mathrm{s}^{-1}$. Fitting parameters and the values of the objective function along with the estimated values of the grinding efficiency and solid-phase mass transfer coefficients are collected in Table 2. The values obtained for the solid-phase mass transfer coefficients, $\mathrm{k}_{\mathrm{s}} \mathrm{a}_{\mathrm{s}}$, are of the same order than those obtained by Sovová [17] when correlating supercritical extraction data of almond oil [18]. The estimated grinding efficiency was similar in all the extractions runs and it can be concluded that the volumetric fraction of broken cells in the corn germ particles is nearly 0.5 . The crossing point, $\mathrm{q}_{\mathrm{c}}$, was found to increase with a decrease in the solubility value, specially marked at low operating pressure.

\subsection{Quality and stability of corn germ oil}

The quality of corn germ oil was evaluated in four samples extracted with SC- $\mathrm{CO}_{2}$ at a constant pressure near $45.0 \mathrm{MPa}$ and two different temperatures of 56 and $84{ }^{\circ} \mathrm{C}$ (runs 9-12).

The physical parameters evaluated (refraction index, density and color) showed no difference between the oils extracted at different temperatures. The average values were a refraction index of $1.472 \pm 0.001$ at $25{ }^{\circ} \mathrm{C}$, a density of $0.92 \pm 0.01 \mathrm{~kg} / \mathrm{L}$ at $20^{\circ} \mathrm{C}$ and a 
color expressed as $100.07,-0.007,-0.012$ corresponding to lightness $\left(L^{*}\right)$, redness $\left(a^{*}\right)$ and yellowness (b*), respectively.

A total of 8 fatty acids were identified and quantified (Table 3) in the different extracts analyzed. It can be observed that the extraction temperature does not influence the fatty acid profile where linoleic acid (more than 50\%) is the major fatty acid, followed by oleic acid and palmitic acid. Vigh et al. [6] reported similar fatty acid composition of corn oil obtained by SFE. Table 3 also includes the fatty acid profile, expressed in weight percentage, for crude germ oil described in literature obtained by pressing, followed in some cases by solvent extraction [22]. It can be concluded from Table 3 that fatty acid composition of SC-oil extracted is typical for corn oil fatty acid profile.

Oil acidity is an important quality parameter related to the presence of free fatty acids (FFA) and other non-lipid acid compounds. FFA are mainly generated by a hydrolysis reaction of triacylglycerides, whereas non-lipid acid compounds, such as acetic acid, may be generated during spoilage of the raw material. Thus, oil acidity depends on several factors related to oil composition, the extraction procedure and the raw material freshness. The acidity index (AI) of the oils extracted at $84{ }^{\circ} \mathrm{C}(1.6 \pm 0.1 \%$ oleic acid $)$ is of the same order as the AI of oils extracted at $56{ }^{\circ} \mathrm{C}(1.3 \pm 0.1 \%$ oleic acid $)$. These values are close to the lowest value of AI described in the literature for crude corn germ oils obtained by conventional extraction (from 1.5 to $4.0 \%$ oleic acid) [22]. These values agree with the results reported by List et al. [2] and Christianson et al. [4] who compare the free fatty acid content of corn oil processing by expeller with those oils resulting of the SFE of corn germ obtaining lower values of acidity in the latter. SFE followed by fractionation has been proposed to obtain oils with high quality and less 
acidity [23]. Some fractionation experiences (R13-15) carried out in this work are explained later.

The sterol content (Table 4) was nearly the same for the two temperatures studied (2.2$2.7 \mathrm{wt} \%$ of the neutral lipids). List et al. [2] reported values slightly lower for the unsaponificable content of $\mathrm{SC}-\mathrm{CO}_{2}$ extracted corn oil, in the range of 1.2-1.3 wt\%, being sterols the majority.

One important quality parameter of fat is the oxidation degree. Lipids oxidation involves three different stages, initiation, propagation and termination which rate depend on the substrates and reaction conditions. Peroxide value is a common parameter evaluated in oils which is related to the primary oxidation products, so it is indicative of the deterioration level of the oil where lipid radicals are attacked by oxygen to form lipid hydroperoxides. Temperature is one of the factors that could affect the initiation stage and therefore the oxidation of the oil [24]. However, in this work, a slightly decrease in the peroxide content of SC oil corn germ obtained at the highest studied extraction temperature can be observed (Table 5). In any case, in this work, considerably high values of the peroxide content have been obtained (Table 5), specially when comparing with other values reported in literature for $\mathrm{SC}-\mathrm{CO}_{2}$ extraction of dry, freshly milled corn germ, which rarely exceed $0.5 \mathrm{meq} / \mathrm{kg}$ [25]. Additionally, List and Friedrich [3] noted that SC- $\mathrm{CO}_{2}$ extracted seed oils undergo rapid deterioration. Many factors affect the oxidative stability of oils, such as fatty acid composition, stability of antioxidants and the presence of prooxidant compounds (FFA, lipid peroxides, or prooxidant metals) [3, 26]. List and Friedrich [3] suggested that the absence of phosphatides could cause a decrease in the positive synergistic effects of tocopherols with phospholipids. In contrast, Calvo et al. [27] suggested that oil instability may be 
related to the trace amounts of oxygen in the $\mathrm{CO}_{2}$. In this case, oxidation would take place without mass transfer limitation since solvent and oil are in the same phase.

The higher values of peroxide content reported in this work for freshly $\mathrm{SC}_{-} \mathrm{CO}_{2}$ extracted oils cannot be due to the tocopherol content in the SC-CO 2 extracted oil since its content (Table 5) is even higher than the values reported for hexane prepress extracted wet corn germ $(1000 \mu \mathrm{g} / \mathrm{g})$ [2]. Tocopherols have been described as one of the most effective antioxidants present in vegetable oils. So, its presence contributes favorably to the conservation and the quality of oils. The tocopherol profile determined by HPLC (Table 5) was qualitatively similar in all the oils extracted; $\gamma$-tocopherol was found to be the major one followed by $\alpha$-tocopherol and $\beta$-tocopherol, along with a small amount of $\delta$-tocopherol (Figure 5). However, a temperature increase seems to increase the yield of tocopherols (Table 5). This fact can explain the reduction in the peroxide content at the highest extraction temperature studied in this work. The antioxidant activity of the tocopherols is mainly due to their ability to donate their phenolic hydrogens to lipid free-radicals [28]. The increase of tocopherol levels, at the highest extraction temperature, increases the antioxidant level of oils (see value of DPPH in Table 5). At constant pressure, the solvent power of carbon dioxide decreases with increasing temperature because of the decreasing density. Based on these results, the tocopherol content found at this highest temperature studied in this work could be due to an increase of vapor pressure of the tocopherols with temperature. In contrast, List et. al. [2] obtained SC-CO $\mathrm{CO}_{2}$ extracted corn germ oil with less amount of tocopherols in the extracted oil when temperature was increased form 70 to $90{ }^{\circ} \mathrm{C}$ at a constant pressure of $82.7 \mathrm{MPa}$ (ranged from 1.840 to $1.180 \mu \mathrm{g} / \mathrm{g}$ at $70{ }^{\circ} \mathrm{C}$ and $90{ }^{\circ} \mathrm{C}$ respectively). Nevertheless, these authors [2] concluded that the reason for this drop was unclear. No 
solubility data of tocopherols in $\mathrm{CO}_{2}$ were found in the literature for the pressure and temperature range used in this work.

\section{Fractionation experiences:}

In order to improve the oil features, an extraction-fractionation process in two separators installed in series was proposed. The first separator was maintained at 10.0 $\mathrm{MPa}$ and $40^{\circ} \mathrm{C}$. The influence of extraction pressure and temperature on the tocopherol content of the oils and on their stability to oxidation was evaluated in these experiences (runs 13-15). It was observed that the fraction collected in the first separator was mostly oil whereas the fraction recovered in the second one was mostly an aqueous emulsion. Furthermore, it was observed that the induction time determined by the rancimat test in the oil fraction recovered in separator $1(1.9 \pm 0.3 \mathrm{~h})$ was significantly higher than the induction time determined in the fraction recovered in separator 2 (0.5 \pm $0.3 \mathrm{~h})$. The higher stability found in the oil fraction recovered in separator 1 may be explained considering that both water and free fatty acids with a high tendency to oxidation, are mostly removed to separator 2 . In any case, the induction time of the oil fraction recovered in the first separator is lower than values reported in literature [26] for hexane Soxhlet extracts of corn germ $(3.91 \pm 0.4 \mathrm{~h})$. This fact was previously explained since SC-CO $\mathrm{CO}_{2}$ extracted oils suffer rapid deterioration.

Figure 6 shows the tocopherol concentration found in the oil fraction recovered in the first separator at different extraction conditions. It can be observed that the total concentration of tocopherols in the oil fraction recovered in separator 1 is almost double when temperature increased from $35^{\circ} \mathrm{C}$ to $86^{\circ} \mathrm{C}$ at a constant extraction pressure of around 49.0 MPa. This result agrees with the values of tocopherol content presented in Table 5 where the effect of extraction temperature on the oil quality was studied. In 
contrast, Wilp and Eggers [5] found that an increase in extraction temperature from $50{ }^{\circ} \mathrm{C}$ to $80{ }^{\circ} \mathrm{C}$ at constant extraction pressure of $50 \mathrm{MPa}$ results in a decrease in tocopherols concentration in the first separator of more than $30 \%$. At constant temperature, around $85^{\circ} \mathrm{C}$, when the extraction pressure is increased from $26 \mathrm{MPa}$ to $49 \mathrm{MPa}$, the tocopherols concentration found in the oil fraction recovered in the first separator was only slightly increased (less than by 10\%). Similar results were obtained by Wilp and Eggers [5] for a decrease in extraction pressure from $50 \mathrm{MPa}$ to $32 \mathrm{MPa}$ at a constant extraction temperature of $50{ }^{\circ} \mathrm{C}$. Based on the results obtained in this work, it could be concluded that the effect of temperature on the extraction of tocopherols is more notably than the effect of pressure.

\section{Conclusions}

Supercritical carbon dioxide extraction has been studied as a procedure to obtain oil from milled corn germ. Extraction experiments have been performed at different extraction pressure $(20.0-53.0 \mathrm{MPa})$, temperature $\left(35-86^{\circ} \mathrm{C}\right)$ and solvent flow rate (4-9 $\left.\mathrm{kg} \mathrm{CO}_{2} / \mathrm{h}\right)$. The extraction curves obtained indicate that the extraction process may be controlled by the solubility of the oil in $\mathrm{SC}-\mathrm{CO}_{2}$ in the first stages of the extraction. The external mass transfer resistance has been found not to be important.

Extraction temperature seems to affect the oil quality yielding oils with higher tocopherol content and therefore higher antioxidant activity and lower oxidation level when the extraction temperature is increased.

SC- $\mathrm{CO}_{2}$ extraction of corn germ permits to obtain oil with good quality with lower values of acidity than for oils obtained by conventional extraction. A high antioxidant capacity was also found for $\mathrm{SC}-\mathrm{CO}_{2}$ corn germ oil. Based on these results, a simpler 
further processing than the traditional one would probably be necessary for $\mathrm{SC}-\mathrm{CO}_{2}$ corn germ oil. On line fractionation in two separators installed in series allows separating the co-extracted water and improves the oil stability against oxidation.

Moreover, the defatted corn germ meal obtained after removing the oil with $\mathrm{SC}-\mathrm{CO}_{2}$ could be used in food formulation due to its good stability and protein quality so more studies will be done to examine the functional properties of the defatted corn germ flour and protein isolates.

\section{Nomenclature}

$\mathrm{a}_{\mathrm{s}}=$ specific area between the regions of intact and broken cells $\left(\mathrm{m}^{-1}\right)$

$\mathrm{C}_{1}, \mathrm{C}_{2}=$ fitting parameters

$\mathrm{e}=$ extraction yield, $\left(\mathrm{kg}\right.$ extract $\cdot \mathrm{kg}$ insoluble solid $\left.^{-1}\right)$

$\mathrm{E}=$ extract $(\mathrm{kg})$

$\mathrm{k}_{\mathrm{s}}=$ solid-phase mass transfer coefficient $\left(\mathrm{s}^{-1}\right)$

$\mathrm{n}=$ number of experimental data

$\mathrm{N}_{\mathrm{m}}=$ charge of insoluble solid $(\mathrm{kg})$

O.F. = objective function

$\mathrm{Q}=$ solvent flow rate $\left(\mathrm{kg} \cdot \mathrm{h}^{-1}\right)$

$\mathrm{q}$ = relative amount of the passed solvent $\left(\mathrm{kg}\right.$ solvent $\cdot \mathrm{kg}$ insoluble solid $\left.{ }^{-1}\right)$

$\mathrm{q}_{\mathrm{c}}=$ relative amount of the passed solvent when all the solute in broken cells has been extracted $\left(\mathrm{kg}\right.$ solvent $\cdot \mathrm{kg}$ insoluble solid $\left.^{-1}\right)$

$r=$ grinding efficiency (fraction of broken cells)

$\mathrm{t}=$ extraction time $(\mathrm{h})$

$\mathrm{x}_{\mathrm{u}}=$ concentration in the untreated solid $\left(\mathrm{kg}\right.$ solute $\cdot \mathrm{kg}$ solid insoluble ${ }^{-1}$ ) 
$\mathrm{y}_{\mathrm{s}}=$ solubility $\left(\mathrm{kg}\right.$ solute $\cdot \mathrm{kg}$ solvent $\left.{ }^{-1}\right)$

\section{Acknowledgments}

S.R. acknowledges the PIRTU program of the JCyL Education Ministry and the European Social Fund. To G. Sanjuan for useful comments.

\section{References}

[1] F.D. Gunstone, Vegetable oils in food technology: composition, properties and uses, Blackwell, 2002.

[2] G.R. List, J.P. Friedrich, D.D. Christianson, Properties and processing of corn oils obtained by extraction with supercritical carbon dioxide, Journal of the American Oil Chemists' Society 61 (1984) 1849-1851.

[3] G.R. List, J.P. Friedrich, Oxidative stability of seed oils extracted with supercritical carbon dioxide, Journal of the American Oil Chemists' Society 66 (1989) 98-101.

[4] D.D. Christianson, J.P. Friedrich, G.R. List, K. Warner, E.B. Bagley, A.C. Stringfellow, G.E. Inglett, Supercritical Fluid Extraction of dry-milled corn germ with carbon dioxide, Journal of Food Science 49 (1984) 229-232.

[5] V.C. Wilp, R. Eggers, Hochdruckextraktion mit mehrstufiger fraktionierender Separation zur schonenden Gewinnung von Keimölen mit hochverdichtetem Kohlendioxid, Fat Science Technology 93 (1991) 348-352.

[6] L. Vigh, B. Simandi, A. Deak, Optimization of supercritical fluid extraction of corn germ oil in a multipurpose extractor, in: T.H. Applewhite (Ed.), Proceedings of the World Conference on Oilseed Technology and Utilization, AOCS press, Champaigne, IL, 1993, p. 433

[7] E. Rónyai, B. Simándi, S. Tömösközi, A. Deák, L. Vigh, Z. Weinbrenner, Supercritical fluid extraction of corn germ with carbon dioxide-ethyl alcohol mixture, The Journal of Supercritical Fluids 14 (1998) 75-81.

[8] J. Friedrich, E. Pryde, Supercritical $\mathrm{CO}_{2}$ extraction of lipid-bearing materials and characterization of the products, Journal of the American Oil Chemists' Society 61 (1984) 223-228.

[9] D.D. Christianson, J.P. Friedrich, Production of food grade corn germ product by supercritical fluid extraction, US4495207, Jan. 22, 1985

[10] E.M. Vaquero, S. Beltrán, M.T. Sanz, Extraction of fat from pigskin with supercritical carbon dioxide, The Journal of Supercritical Fluids 37 (2006) 142-150.

[11] CIE, Colorimetry, Second ed., Central Bureau of the Commission Internationale de L’Eclairage, Vienna, 1986. 
[12] AOAC, Fatty acids in encapsulated fish oils and fish oil methyl and ethyl esters. Gas chomatographic method, AOAC (1995).

[13] A. Schaefer, T. Küchler, T.J. Simat, H. Steinhart, Migration of lubricants from food packagings: Screening for lipid classes and quantitative estimation using normalphase liquid chromatographic separation with evaporative light scattering detection, Journal of Chromatography A 1017 (2003) 107-116.

[14] IUPAC, Determination of tocopherols and tocotrienols in vegetable oils and fats by high performance liquid chromatography, IUPAC (1988).

[15] W. Brand-Williams, M.E. Cuvelier, C. Berset, Use of a free radical method to evaluate antioxidant activity, Food science and Technology 28 (1995) 25-30.

[16] U. Salgın, O. Döker, A. Calımlı, Extraction of sunflower oil with supercritical $\mathrm{CO}_{2}$ : Experiments and modeling, The Journal of Supercritical Fluids 38 (2006) 326-331.

[17] H. Sovová, Mathematical model for supercritical fluid extraction of natural products and extraction curve evaluation, The Journal of Supercritical Fluids 33 (2005) 35-52.

[18] E. Reverchon, C. Marrone, Modeling and simulation of the supercritical $\mathrm{CO}_{2}$ extraction of vegetable oils, The Journal of Supercritical Fluids 19 (2001) 161-175.

[19] J.M. del Valle, J.C. de la Fuente, E. Uquiche, A refined equation for predicting the solubility of vegetable oils in high-pressure $\mathrm{CO}_{2}$, The Journal of Supercritical Fluids 67 (2012) 60-70.

[20] B.M.C. Soares, F.M.C. Gamarra, L.C. Paviani, L.A.G. Gonçalves, F.A. Cabral, Solubility of triacylglycerols in supercritical carbon dioxide, The Journal of Supercritical Fluids 43 (2007) 25-31.

[21] E. Langa, G.D. Porta, A.M.F. Palavra, J.S. Urieta, A.M. Mainar, Supercritical fluid extraction of Spanish sage essential oil: Optimization of the process parameters and modelling, The Journal of Supercritical Fluids 49 (2009) 174-181.

[22] L.A. Johnson, Corn: the mayor cereal of the Americas, in: K. Kulp, J.G. Ponte (Eds.), Handbook of cereal science and technology, Marcel Dekker, New York, 2004.

[23] N. Rubio-Rodríguez, S.M. de Diego, S. Beltrán, I. Jaime, M.T. Sanz, J. Rovira, Supercritical fluid extraction of fish oil from fish by-products: A comparison with other extraction methods, Journal of Food Engineering 109 (2012) 238-248.

[24] K. Anna, Lipid Oxidation in Food Systems, in: A.K. Zdzisław E. Sikorski (Ed.), Chemical and Functional Properties of Food Lipids, CRC Press, 2002.

[25] G.R. List, J.P. Friedrich, J.W. King, Supercritical $\mathrm{CO}_{2}$ extraction and processing of oilseeds, Oil Mill Gazetteer December (1989) 28-34.

[26] J.K. Winkler-Moser, L. Breyer, Composition and oxidative stability of crude oil extracts of corn germ and distillers grains, Industrial Crops and Products 33 (2011) 572578. 
[27] L. Calvo, M. Cocero, J. Díez, Oxidative stability of sunflower oil extracted with supercritical carbon dioxide, Journal of the American Oil Chemists' Society 71 (1994) 1251-1254.

[28] A. Kamal-Eldin, L.A. Appelqvist, The chemistry and antioxidant properties of tocopherols and tocotrienols, Lipids 31 (1996) 671-701. 
Table 1. Experimental conditions in the SFE of corn germ oil with SC-CO

\begin{tabular}{|c|c|c|c|c|}
\hline Run & $\mathrm{P}(\mathrm{MPa})$ & $\mathrm{T}\left({ }^{\circ} \mathrm{C}\right)$ & $\begin{array}{l}\text { Solvent flow rate, } \\
\qquad(\mathrm{kg} \mathrm{CO} 2 / \mathrm{h})\end{array}$ & Fractionation \\
\hline $\mathrm{R} 1$ & $45.0 \pm 2.0$ & $40 \pm 1.5$ & $8.5 \pm 0.8$ & No \\
\hline $\mathrm{R} 2$ & $45.0 \pm 2.0$ & $63 \pm 1.5$ & $8.8 \pm 0.8$ & No \\
\hline R3 & $45.5 \pm 2.0$ & $79 \pm 2$ & $9.5 \pm 0.9$ & No \\
\hline $\mathrm{R} 4$ & $45.0 \pm 1.8$ & $85 \pm 2.5$ & $8.0 \pm 0.9$ & No \\
\hline $\mathrm{R} 5$ & $30.0 \pm 1.5$ & $80 \pm 1.5$ & $10.0 \pm 0.7$ & No \\
\hline R6 & $21.0 \pm 0.5$ & $39 \pm 1$ & $9.0 \pm 0.7$ & No \\
\hline R7 & $52.5 \pm 2.0$ & $80 \pm 2$ & $6 \pm 0.5$ & No \\
\hline R8 & $44.2 \pm 2.0$ & $78 \pm 2$ & $3.9 \pm 0.5$ & No \\
\hline R9 & $45.9 \pm 2.0$ & $56 \pm 2$ & $10 \pm 0.9$ & No \\
\hline R10 & $45.5 \pm 1.7$ & $57 \pm 1.5$ & $8 \pm 0.7$ & No \\
\hline $\mathrm{R} 11$ & $44.0 \pm 1.5$ & $84 \pm 1.5$ & $6 \pm 0.7$ & No \\
\hline R12 & $43.1 \pm 2.0$ & $84 \pm 2$ & $5 \pm 0.5$ & No \\
\hline R13 & $50.0 \pm 1.5$ & $35 \pm 1.5$ & $11 \pm 0.7$ & Yes \\
\hline R14 & $48.0 \pm 1.5$ & $86 \pm 1.5$ & $7 \pm 0.9$ & Yes \\
\hline R15 & $25.8 \pm 2.0$ & $85 \pm 1.5$ & $9 \pm 0.9$ & Yes \\
\hline
\end{tabular}


Table 2. Values of the $\mathrm{C}_{1}, \mathrm{C}_{2}$ parameters, $\mathrm{q}_{\mathrm{c}}$, estimated grinding efficiency $\mathrm{r}$, solidphase mass transfer coefficient, $\mathrm{k}_{\mathrm{s}} \mathrm{a}_{\mathrm{s}}$ and O.F.

\begin{tabular}{lcccccc}
\hline Experiment & $\mathrm{C}_{1}$ & $\mathrm{C}_{2}$ & $\mathrm{q}_{\mathrm{c}}$ & $\mathrm{r}$ & $\mathrm{k}_{\mathrm{s}} \mathrm{a}_{\mathrm{s}}$ & O.F. \\
\hline $\mathrm{R} 1$ & 0.6049 & 0.0054 & 25 & 0.43 & $1.9 \cdot 10^{-5}$ & $5.0 \cdot 10^{-3}$ \\
$\mathrm{R} 2$ & 0.6728 & 0.0144 & 26 & 0.44 & $5.0 \cdot 10^{-5}$ & $3.2 \cdot 10^{-3}$ \\
$\mathrm{R} 3$ & 0.6546 & 0.0188 & 23 & 0.47 & $6.6 \cdot 10^{-5}$ & $5.7 \cdot 10^{-3}$ \\
$\mathrm{R} 4$ & 0.6586 & 0.0214 & 22 & 0.48 & $6.2 \cdot 10^{-5}$ & $3.8 \cdot 10^{-3}$ \\
R5 & 0.6419 & 0.0050 & 55 & 0.44 & $2.0 \cdot 10^{-5}$ & $1.5 \cdot 10^{-3}$ \\
R6 & 0.7478 & 0.0023 & 75 & 0.32 & $1.0 \cdot 10^{-5}$ & $1.2 \cdot 10^{-2}$ \\
R7 & 0.7234 & 0.0297 & 17 & 0.44 & $7.1 \cdot 10^{-5}$ & $7.7 \cdot 10^{-3}$ \\
R8 & 0.6509 & 0.0158 & 28 & 0.48 & $2.3 \cdot 10^{-5}$ & $3.2 \cdot 10^{-3}$ \\
\hline
\end{tabular}


Table 3. Fatty acid profile of corn germ oil extracted with $\mathrm{SC}-\mathrm{CO}_{2}$ and comparison with crude oil.

\begin{tabular}{|c|c|c|c|c|c|c|}
\hline Fatty acid & $\begin{array}{c}\mathrm{R} 9 \\
56^{\circ} \mathrm{C} \\
\mathrm{mg} / \mathrm{g} \text { oil }\end{array}$ & $\begin{array}{c}\mathrm{R} 10 \\
57^{\circ} \mathrm{C} \\
\mathrm{mg} / \mathrm{g} \text { oil }\end{array}$ & $\begin{array}{c}\mathrm{R} 11 \\
84^{\circ} \mathrm{C} \\
\mathrm{mg} / \mathrm{g} \text { oil }\end{array}$ & $\begin{array}{c}\mathrm{R} 12 \\
84{ }^{\circ} \mathrm{C} \\
\mathrm{mg} / \mathrm{g} \text { oil }\end{array}$ & $\begin{array}{c}\text { R9-R12 } \\
\text { \% (g/100 g } \\
\text { fatty acids) }\end{array}$ & $\begin{array}{l}\text { Crude oil \% } \\
\text { (g/100 g fatty } \\
\text { acids) }{ }^{[22]}\end{array}$ \\
\hline C16:0 & $107 \pm 1$ & $106 \pm 3$ & $105 \pm 3$ & $106 \pm 1$ & $12.5 \pm 0.5$ & $11.1-12.8$ \\
\hline C18:0 & $20 \pm 1$ & $20 \pm 1$ & $19 \pm 1$ & $19 \pm 1$ & $2.3 \pm 0.2$ & $1.4-2.2$ \\
\hline C18:1 n-9 & $245 \pm 1$ & $240 \pm 4$ & $234 \pm 6$ & $234 \pm 1$ & $28.2 \pm 0.9$ & $22.6-36.1$ \\
\hline C18:1 n-7 & $5 \pm 1$ & $5 \pm 1$ & $5 \pm 1$ & $5 \pm 1$ & $0.6 \pm 0.1$ & - \\
\hline C18:2 n-6 & $475 \pm 2$ & $467 \pm 9$ & $455 \pm 13$ & $457 \pm 2$ & $54.8 \pm 1.8$ & 49.0-61.9 \\
\hline C18:3 n-3 & $8 \pm 1$ & $8 \pm 1$ & $8 \pm 1$ & $8 \pm 1$ & $1.0 \pm 0.1$ & $0.4-1.6$ \\
\hline C20:0 & $4 \pm 1$ & $2 \pm 1$ & $3 \pm 1$ & $3 \pm 1$ & $0.4 \pm 0.1$ & $0.0-0.2$ \\
\hline C20:1 n-9 & $3 \pm 1$ & $2 \pm 1$ & $3 \pm 1$ & $3 \pm 1$ & $0.3 \pm 0.1$ & - \\
\hline $\begin{array}{l}\text { Saturated fatty } \\
\text { acids }\end{array}$ & $131 \pm 3$ & $128 \pm 5$ & $127 \pm 5$ & $128 \pm 3$ & $15.2 \pm 0.8$ & $12.5-15.2$ \\
\hline $\begin{array}{l}\text { Monounsaturated } \\
\text { fatty acids }\end{array}$ & $253 \pm 3$ & $247 \pm 6$ & $242 \pm 8$ & $242 \pm 3$ & $29.1 \pm 1.1$ & $22.6-36.1$ \\
\hline $\begin{array}{l}\text { Polyunsaturated } \\
\text { fatty acids }\end{array}$ & $483 \pm 3$ & $475 \pm 10$ & $463 \pm 14$ & $465 \pm 3$ & $55.7 \pm 2.0$ & 49.4-63.5 \\
\hline Total fatty acids & $867 \pm 9$ & $850 \pm 21$ & $832 \pm 27$ & $835 \pm 9$ & $100.0 \pm 3.9$ & 84.5-114.8 \\
\hline
\end{tabular}


Table 4. Neutral lipids profile of corn germ oil extracted with $\mathrm{SC}-\mathrm{CO}_{2}$

\begin{tabular}{lllll}
\hline \multirow{2}{*}{ Neutral lipids } & \multicolumn{4}{c}{ \% wt. in oil } \\
\cline { 2 - 5 } & $\mathrm{R} 9$ & $\mathrm{R} 10$ & $\mathrm{R} 11$ & $\mathrm{R} 12$ \\
\hline Triacylglycerides (TAG) & $95.1 \pm 0.8$ & $94.4 \pm 0.7$ & $95.3 \pm 0.4$ & $95.4 \pm 0.4$ \\
Free fatty acids (FFA) & $0.8 \pm 0.2$ & $1.1 \pm 0.1$ & $1.1 \pm 0.1$ & $1.0 \pm 0.1$ \\
& & & & \\
Sterols (St) & $2.3 \pm 0.4$ & $2.7 \pm 0.2$ & $2.2 \pm 0.1$ & $2.2 \pm 0.1$ \\
Others & & & & \\
\hline
\end{tabular}


Table 5. Peroxide value, antioxidant capacity (DPPH) and tocopherol content of SC$\mathrm{CO}_{2}$ extracted oils

\begin{tabular}{|c|c|c|c|c|}
\hline & $\begin{array}{c}\mathrm{R} 9 \\
56^{\circ} \mathrm{C}\end{array}$ & $\begin{array}{l}\mathrm{R} 10 \\
57^{\circ} \mathrm{C}\end{array}$ & $\begin{array}{l}\mathrm{R} 11 \\
84^{\circ} \mathrm{C}\end{array}$ & $\begin{array}{l}\mathrm{R} 12 \\
84{ }^{\circ} \mathrm{C}\end{array}$ \\
\hline $\begin{array}{l}\text { Peroxide Value } \\
\text { (meq/ kg oil) }\end{array}$ & $25 \pm 2$ & $24 \pm 1$ & $21 \pm 1$ & $20 \pm 1$ \\
\hline $\begin{array}{l}\text { DPPH (mmol BHT/ } \\
\text { kg oil) }\end{array}$ & $22 \pm 3$ & $25 \pm 2$ & $34 \pm 1$ & $32 \pm 3$ \\
\hline $\begin{array}{l}\text { Tocopherol content } \\
\text { (ppm) }\end{array}$ & $1082 \pm 14$ & $1090 \pm 3$ & $1481 \pm 8$ & $1397 \pm 17$ \\
\hline$\alpha$-tocopherol & $71 \pm 5$ & $59 \pm 1$ & $97 \pm 2$ & $86 \pm 2$ \\
\hline$\beta$-tocopherol & $65 \pm 1$ & $63 \pm 1$ & $65 \pm 1$ & $64 \pm 1$ \\
\hline$\gamma$-tocopherol & $945 \pm 8$ & $967 \pm 1$ & $1303 \pm 4$ & $1232 \pm 11$ \\
\hline$\delta$-tocopherol & ND & ND & $17 \pm 1$ & $15 \pm 3$ \\
\hline
\end{tabular}




\section{List of Figure captions:}

Figure 1. Influence of extraction temperature on corn germ oil extraction yield at a constant pressure of $45.0-46.0 \mathrm{MPa}\left(\circ 40^{\circ} \mathrm{C} ; \triangle 63^{\circ} \mathrm{C}\right.$; $\diamond 79^{\circ} \mathrm{C}$; $\left.\square 85^{\circ} \mathrm{C}\right)$. The solid lines correspond to the model of Sovová [17].

Figure 2. Influence of extraction pressure on corn germ oil extraction yield at constant extraction temperature of (a) $40^{\circ} \mathrm{C}(\square 30 \mathrm{MPa} ; \triangle 45 \mathrm{MPa}$; $\circ 53 \mathrm{MPa})$ (b) $80{ }^{\circ} \mathrm{C}$ (

$21 \mathrm{MPa}$; $~ 45 \mathrm{MPa}$ ). The solid lines correspond to the model of Sovová [17].

Figure 3. Influence of solvent flow rate on corn germ oil extraction yield at a constant

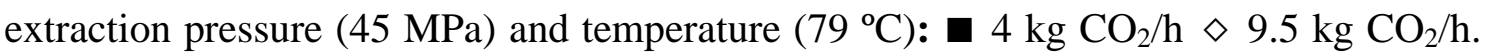
The solid lines correspond to the model of Sovová [17].

Figure 4. Corrected (at $40^{\circ} \mathrm{C}$ ) experimental solubility values of corn germ oil as function of pure $\mathrm{CO}_{2}$ density. ( $\bullet$ experimental data points); $(-)$ prediction of del Valle et al. [19] General Model; (- - - ) error limits of the General Model; solubility data from Soares et al. [20] (口); slope datum from Rónyai et al. [7] (०).

Figure 5. Chromatogram of tocopherols in the $\mathrm{SC}-\mathrm{CO}_{2}$ extracted corn oil.

Figure 6. Tocopherol concentration of fractionated oils in the first separator (10.0 MPa and $40{ }^{\circ} \mathrm{C}$ ) at different extraction temperatures (a) and pressures (b). 


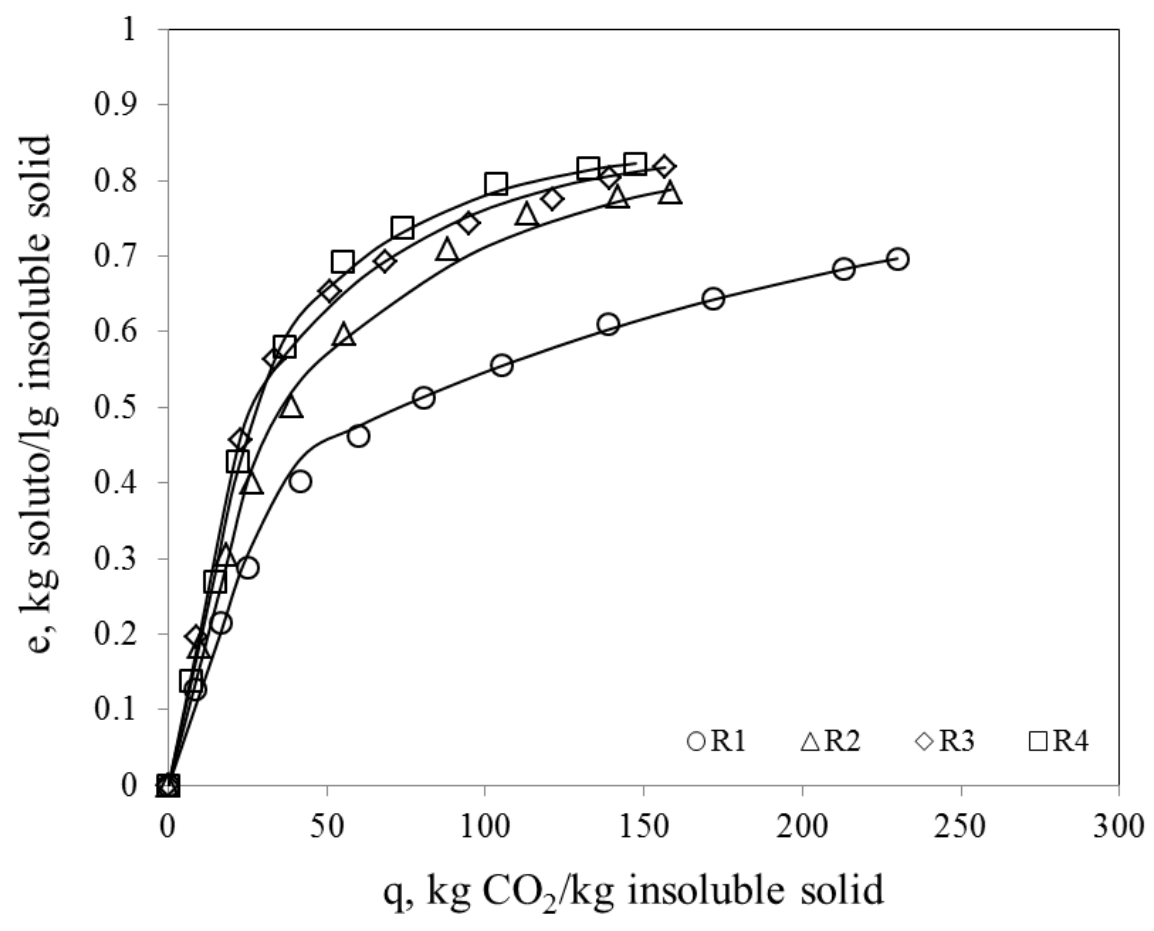

Figure 1. Influence of extraction temperature on corn germ oil extraction yield at a constant pressure of $45.0-46.0 \mathrm{MPa}\left(\circ 40^{\circ} \mathrm{C} ; \triangle 63^{\circ} \mathrm{C} ; \diamond 79^{\circ} \mathrm{C} ; \square 85^{\circ} \mathrm{C}\right)$. The solid lines correspond to the model of Sovová [17]. 

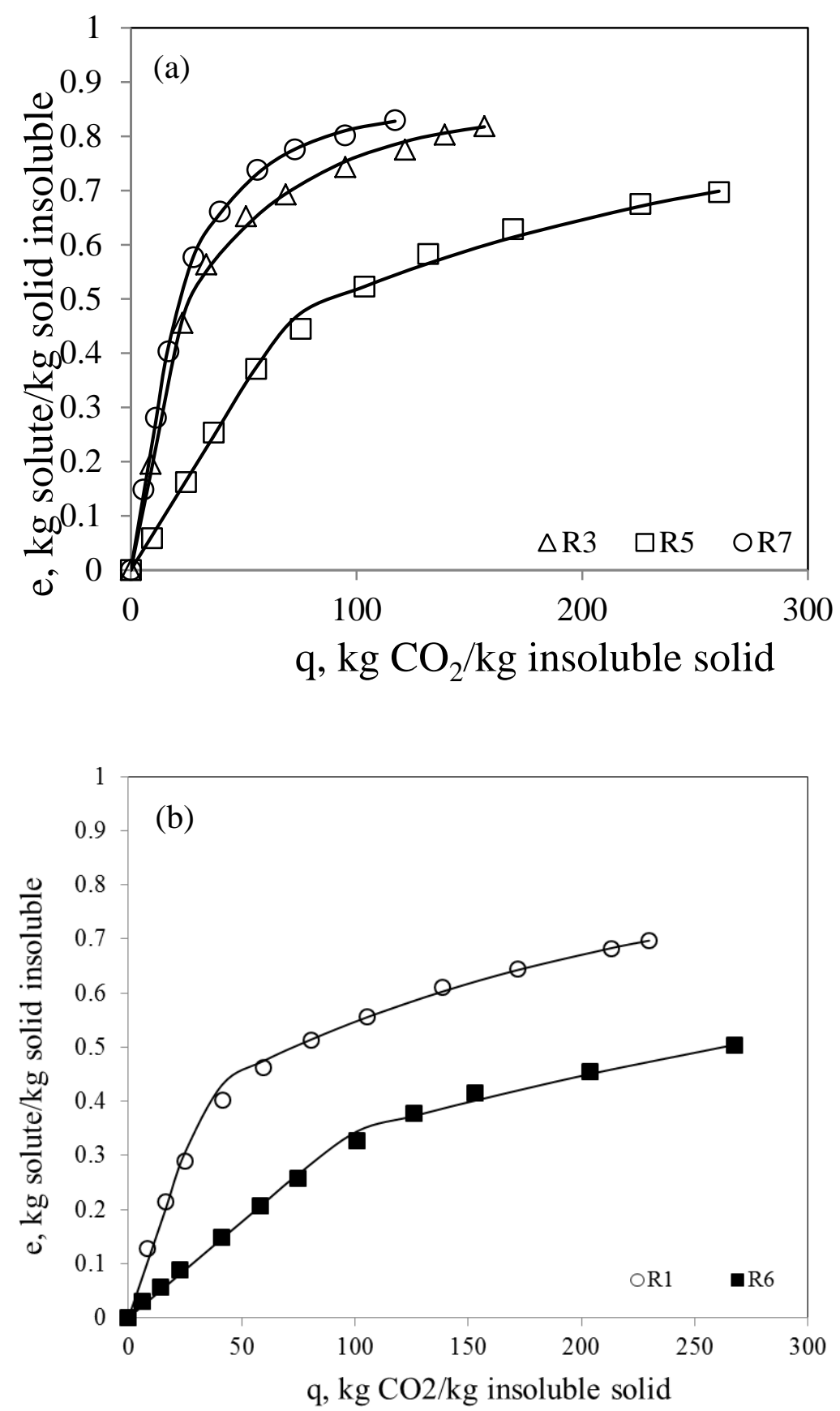

Figure 2. Influence of extraction pressure on corn germ oil extraction yield at constant extraction temperature of (a) $40{ }^{\circ} \mathrm{C}(\square 30 \mathrm{MPa}$; $\triangle 45 \mathrm{MPa}$; $\circ 53 \mathrm{MPa})$ (b) $80{ }^{\circ} \mathrm{C}$ ( $21 \mathrm{MPa} ;$ o $45 \mathrm{MPa}$ ). The solid lines correspond to the model of Sovová [17]. 


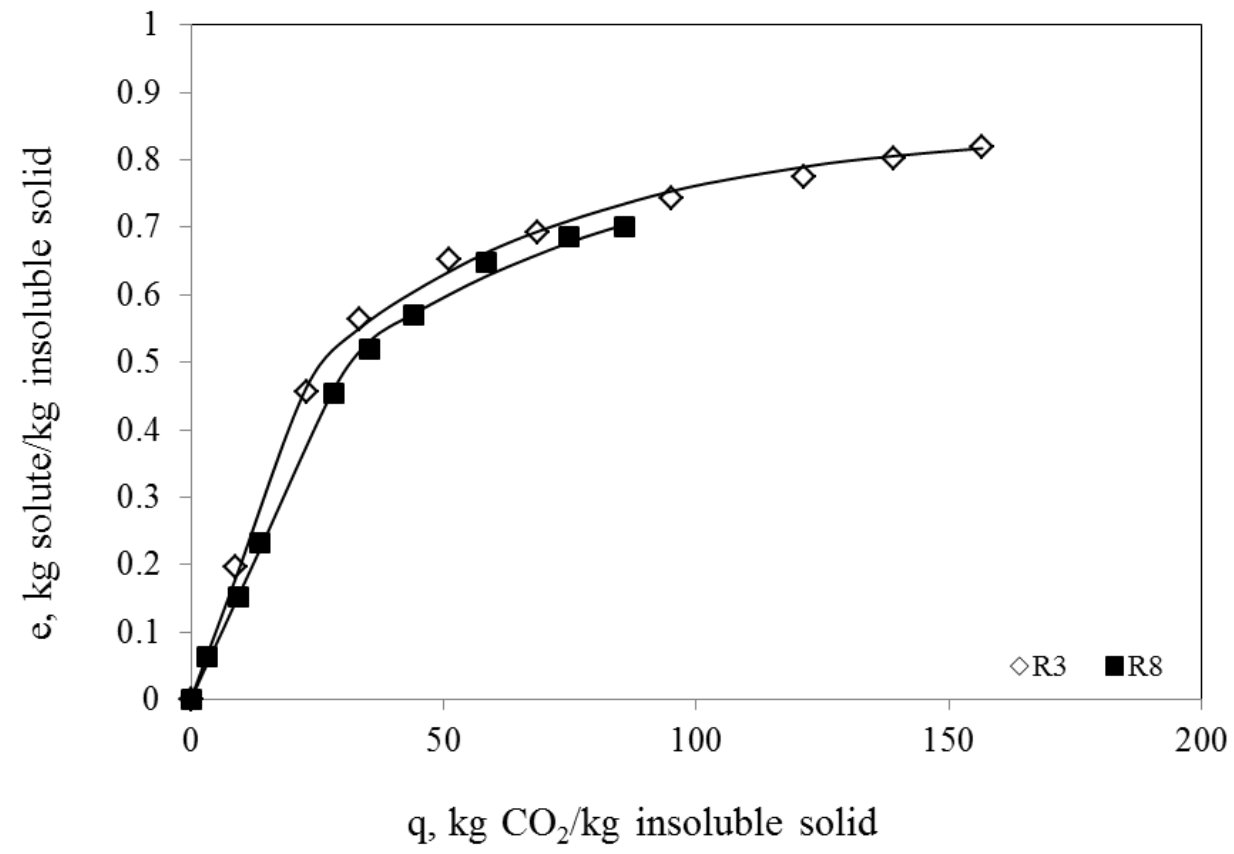

Figure 3. Influence of solvent flow rate on corn germ oil extraction yield at a constant extraction pressure (45 MPa) and temperature $\left(79{ }^{\circ} \mathrm{C}\right):-4 \mathrm{~kg} \mathrm{CO} / 2 / \mathrm{h} \diamond 9.5 \mathrm{~kg} \mathrm{CO} / \mathrm{h}$. The solid lines correspond to the model of Sovová [17]. 


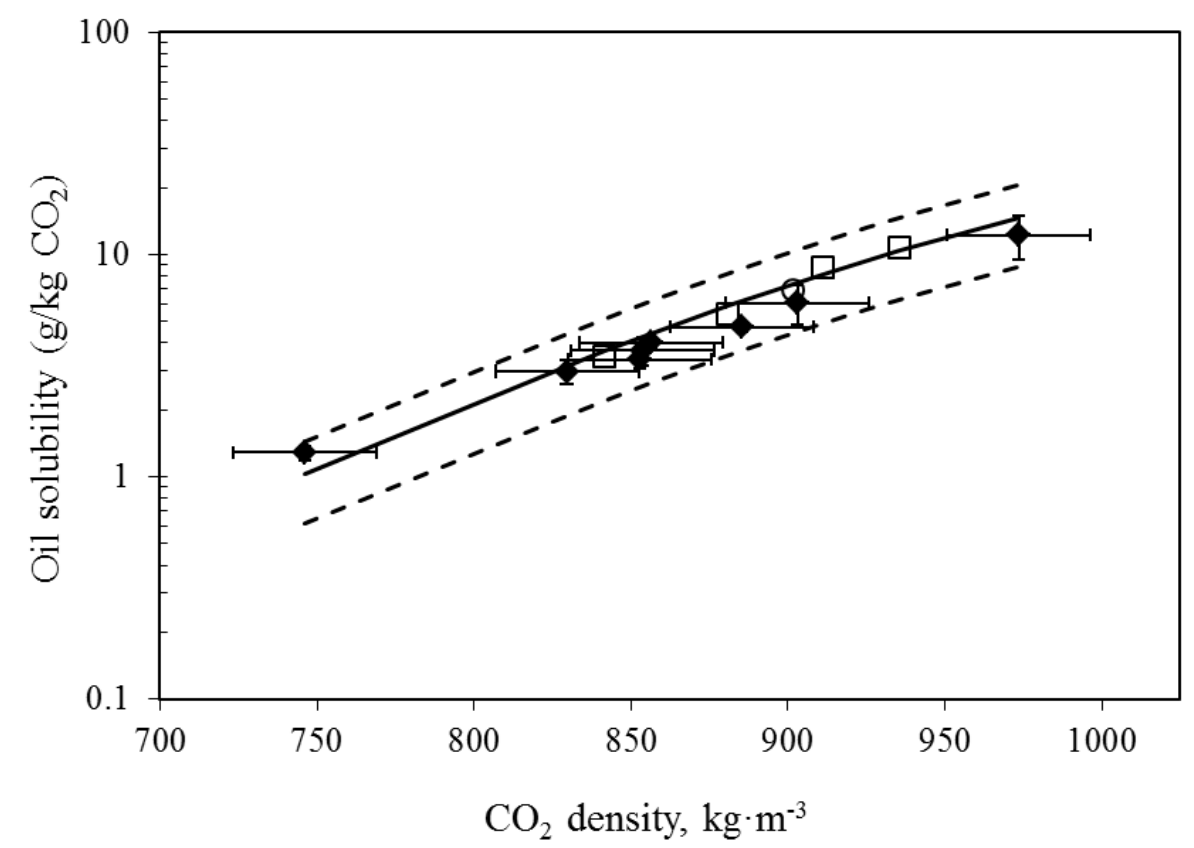

Figure 4. Corrected (at $40^{\circ} \mathrm{C}$ ) experimental solubility values of corn germ oil as function of pure $\mathrm{CO}_{2}$ density. ( $\bullet$ experimental data points); $(-)$ prediction of del Valle et al. [19] General Model; (- - - ) error limits of the General Model; solubility data from Soares et al. [20] (口); slope datum from Rónyai et al. [7](०). 


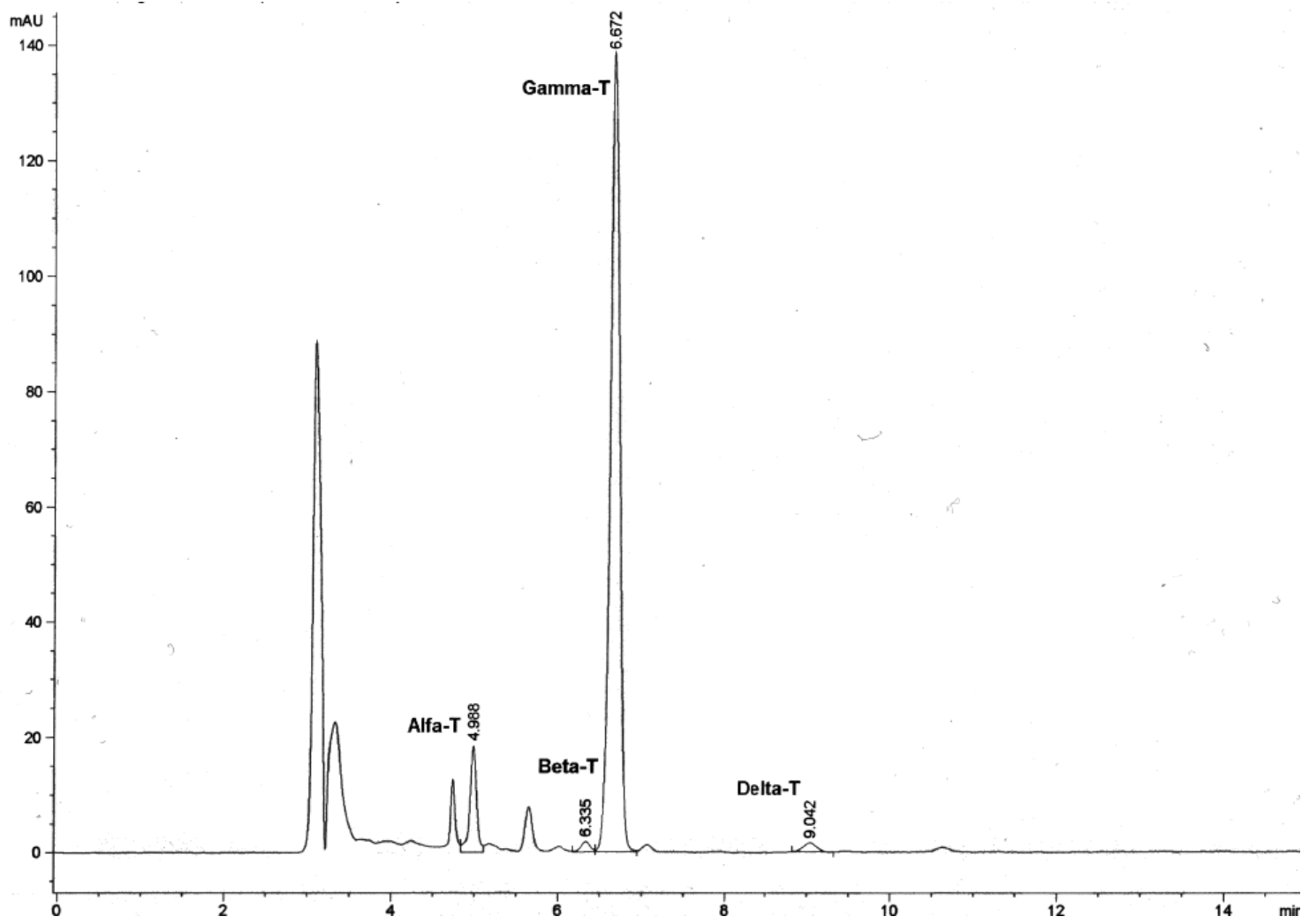

Figure 5. Chromatogram of tocopherols in the $\mathrm{SC}-\mathrm{CO}_{2}$ extracted corn oil. 

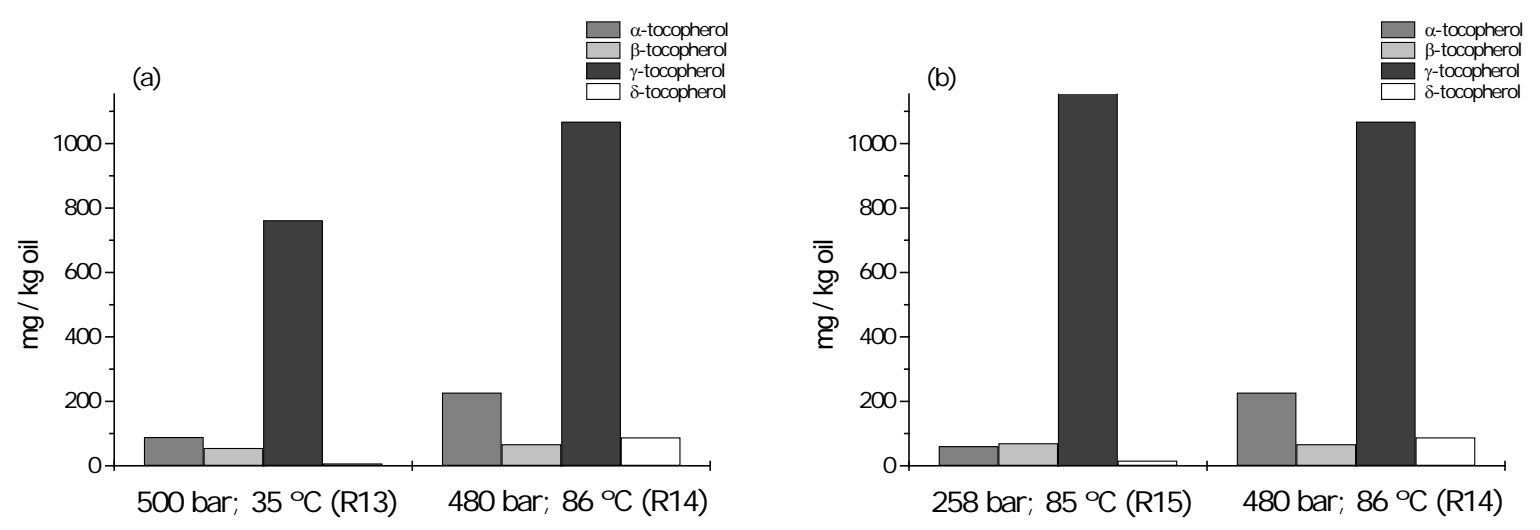

Figure 6. Tocopherol concentration of fractionated oils in the first separator (10.0 MPa and $40^{\circ} \mathrm{C}$ ) at different extraction temperatures (a) and pressures (b). 